\title{
Antibodies as Currency: COVID-19's Golden Passport
}

\author{
Katrina A. Bramstedt (iD
}

Received: 8 May 2020 / Accepted: 17 July 2020

(C) Journal of Bioethical Inquiry Pty Ltd. 2020

\begin{abstract}
Due to COVID-19, the fragile economy, travel restrictions, and generalized anxieties, the concept of antibodies as a "declaration of immunity" or "passport" is sweeping the world. Numerous scientific and ethical issues confound the concept of an antibody passport; nonetheless, antibodies can be seen as a potential currency to allow movement of people and resuscitation of global economics. Just as financial currency can be forged, so too is the potential for fraudulent antibody passports. This paper explores matters of science, ethics, and identity theft, as well as the problems of bias and discrimination that could promulgate a world of pandemic "golden passports."
\end{abstract}

Keywords COVID-19 Pandemic $\cdot$ Ethics $\cdot$ Antibody Travel medicine $\cdot$ Public health $\cdot$ Identity theft $\cdot$ Health law

The concept of a "passport" is changing due to COVID19. Conventionally, a passport is an official document issued by a government agency to certify identity and

\footnotetext{
K. A. Bramstedt

Luxembourg Agency for Research Integrity (LARI), 6, avenue des Hauts-Fourneaux, L-4362 Esch-sur-Alzette, Luxembourg

K. A. Bramstedt $(\bowtie)$

Bond University Medical Program, Gold Coast, Queensland, Australia

e-mail: txbioethics@yahoo.com

e-mail: kbramste@bond.edu.au
}

citizenship, as well as authorizing travel. "Golden passports" have been sought after by the wealthy as a method to gain citizenship-by-investment in regions of the world that have advantageous tax structures (Shachar 2017). In the era of COVID-19, antibodies (proteins made by the immune system to fight infection) are posed as a form of currency that can permit "certified" individuals to return to work or travel (see, for example, Bartlett 2020). In this way, antibodies for SARS-CoV-2 (severe acute respiratory syndrome coronavirus type 2-the COVID-19 coronavirus) are potentially the new golden passport, but the concept is a moving target with clinical unknowns, as well as legal and ethical complexity (Phelan 2020; Persad and Emanuel 2020).

Research and innovation normally move at the pace of a marathon, but during a pandemic the pace is more like a sprint, creating an environment which is ripe for human error, as well as research and business misconduct, amid a sea of scientific uncertainty, anxious patients and families, and economic frailty (Bramstedt 2020). In the United States, at least 160 types of antibody test kits have been available; however, due to limited regulatory assessment in the race to release product, these have questionable performance (Burton 2020). Sensitivity and specificity performance thresholds are now set (U.S. Food and Drug Administration 2020a), and the results are catalogued in an open access format (U.S. Food and Drug Administration 2020b). Yet even with a robust quality standard and improved regulatory screening of test kits, there remains more questions to address. 


\section{At-Home Testing}

Home testing for the identification of SARS-CoV-2 RNA [active infection] is already available in the United States (U.S. Food and Drug Administration 2020c). This permits symptomatic people [patients] to selfswab with a home collection kit, sending their nasal swab sample via priority shipping to the approved laboratory for analysis. Kits are registered online with a twelve-digit barcode that links the patient to the collection tube. Positive results are reported to the patient and the public health authority. Positive results can facilitate a clinical treatment plan, but what is the role of negative results? How long does the negative result last and when should such patients be retested? These questions about negative results are important because there can be a window of time during which patients (with and without symptoms) are infected and potential vectors of the disease. Also, knowing the true source of the sample is vital; this is not necessarily the name of the person linked to the barcode. There are many ways to fake an identity, but genetic linking can give true identity. However, the associated patient documents for the RNA home test do not mention any provision for genetic testing to identify the sample owner (LabCorp 2020a, 2020b).

Currently, COVID-19 antibody testing requires an in-person visit for blood sampling in the inpatient or outpatient setting. This in-person visit allows for personal identification verification of the sample provider. If COVID-19 antibody testing evolves to the home setting using a finger-stick blood sample, the issue of identity verification emerges (Brown 2012). This is because the perceived social and economic value of a positive antibody result is significant, and fraudulent sampling can occur with ease (for example, submission of a sample from someone already confirmed to be COVID-19 antibody positive). Without verification of the true owner of the antibody specimen, identify theft could be a new problem of this pandemic.

\section{Fraudulent Certifications/Passports}

With the COVID-19 pandemic causing a fragile worldwide economy and millions of people unemployed (Congressional Research Service 2020), there is a risk of antibody certificates being viewed as the "golden passport" to return to work and travel. The WHO
(World Health Organization 2020) has stated the presence of SARS-CoV-2 antibodies is not a guarantee that a person cannot be reinfected $(\mathrm{Fu}$, Chen, and Wang 2020). Also, some people might have false positive tests for SARS-CoV-2 antibodies and have zero protection against their first infection (Ismail 2020). Conversely, another potential situation which has been observed is patients have prior tested positive for SARS-CoV-2 RNA (active infection with or without symptoms) and yet test negative for SARS-CoV-2 antibodies (Centers for Disease Control and Prevention 2020). Those with negative antibody test results could use various forms of identity theft to confer themselves a positive test result.

Even if a positive result were scientifically confirmed to confer immunity, there would be the additional matter of a validity date/expiration date. Also, there is the matter of creating a globally recognized standard for certification [test method, titres], robust certification agencies, and the logistical issues of documentation language so that certificates could be readable across countries.

\section{Preventing a Caste System}

Attempting to rescue the economy with a scientifically unproven antibody passport is problematic for many reasons, including a false sense of health security. But if a COVID-19 antibody passport could be scientifically validated and distributed via a system with globalized recognition, there is the potential for a caste system to result; namely the haves and the have nots of "golden passports." Those holding such a passport could benefit from work and movement rights similar to the rights generated by customary immigration visas and passports. Systems to prevent fraud with the antibody passport could be implemented using biometrics; however, there could remain a group of people for whom work and travel could have restrictions. This could create a coercion for people to intentionally expose themselves to the virus (Kates 2020) in order to "earn" a passport that could provide them valuable privileges.

Ethically, work and travel restrictions are appropriate for people who are actively infected. Work and travel restrictions could also be appropriate for others as well, but care must be taken to not psychologically or otherwise damage those who are "not immune" from COVID-19. Stigma as well as other harms could potentially negatively impact a person's employability, 
promotability, insurance rates, access to housing, etc. These ethical concerns heighten the need for policy advisors to reflect beyond the science when they consider enacting antibody passports.

In the future there might be a call for COVID-19 vaccination certificates (Phelan 2020); however, this too will generate legal and ethical debate. There will be issues of cost, access, safety, and consent, but also many facets of the current antibody issue will be present as well; namely, antibody titres, re-infectivity, and expiry/ boosters. The ethical call is to proactively reflect on these antibody-related matters to create systems which are clinically safe and fraud resistant and avoid discrimination.

Funding Information No funding was received for this work.

\section{Compliance with ethical standards}

Conflicts of Interest Nothing to declare.

\section{References}

Bartlett, J. 2020. Chile's “immunity passport” will allow recovered coronavirus patients to break free from lockdown, get back to work. Washington Post, April 20. https://www. washingtonpost.com/world/the_americas/chile-coronavirusimmunity-passport-antibody-testing-card/2020/04/20 /8daef326-826d-11ea-81a3-9690c9881111_story.html Accessed May 6, 2020.

Bramstedt, K.A. 2020. Ethical and robust research during pandemics: HOW? [webcast]. April 30. https://www.youtube. $\mathrm{com} /$ watch?v=GUHcwPqpp2s. Accessed May 6, 2020.

Brown, C.L. 2012. Health-care data protection and biometric authentication policies: Comparative culture and technology acceptance in China and in the United States. Review of Policy Research 29(1): 141-159.

Burton, T.M. 2020. FDA sets standards for coronavirus antibody tests in crackdown on fraud. The Wall Street Journal, May 4. https://www.wsj.com/articles/fda-sets-standards-forcoronavirus-antibody-tests-in-crackdown-on-fraud11588605373. Accessed May 6, 2020.

Centers for Disease Control and Prevention. 2020. Test for past infection. https://www.cdc.gov/coronavirus/2019ncov/testing/serology-overview.html. Accessed 18 May 2020.
Congressional Research Service. 2020. Global economic effects of COVID-19. https://tinyurl.com/yc3465s6 Accessed May 6, 2020.

Fu, W., Q. Chen, and T. Wang. 2020. Letter to the editor: Three cases of redetectable positive SARS-CoV-2 RNA in recovered COVID-19 patients with antibodies. Journal of Medical Virology. ePub ahead of print, May 5. https://doi.org/10.1002 /jmv.25968.

Ismail, A.A.A. 2020. Serological tests for COVID-19 antibodies: Limitations must be recognized. Annals of Clinical Biochemistry 57(4): 274-276.

Kates, O.S. 2020. Show me your passport: Ethical concerns about Covid-19 antibody testing as key to reopening public life. Hastings Bioethics Forum, May 5. https://www. thehastingscenter.org/show-me-your-passport-ethicalconcerns-about-covid-19-antibody-testing-as-a-key-toreopening-public-life/. Accessed May 6, 2020.

LabCorp 2020a. Let's get started [instructions for use]. https://www.fda.gov/media/137154/download. Accessed May 6, 2020.

.2020b. Fact sheet for patients: LabCorp's COVID-19 RTPCR test. https://www.fda.gov/media/136150/download. Accessed May 6, 2020.

Persad, G., and E.J. Emanuel. 2020. The ethics of COVID-19 immunity-based licenses ("immunity passports"). JAMA 323(22): 2241-2242.

Phelan, A.L. 2020. COVID-19 immunity passports and vaccination certificates: Scientific, equitable, and legal challenges. Lancet 395(10237): 1595-1598.

Shachar, A. 2017. Citizenship for sale? In Oxford handbook of citizenship, edited by A. Shachar, R. Bauböck, I. Bloemraad, and M.Vink, 789-816. London: Oxford University Press.

U.S. Food and Drug Administration. 2020a. Insight into FDA's revised policy on antibody tests: Prioritizing access and accuracy, May 4. https://www.fda.gov/news-events/fdavoices/insight-fdas-revised-policy-antibody-testsprioritizing-access-and-accuracy. Accessed May 6, 2020.

. 2020b. EUA authorized serology test performance. https://www.fda.gov/medical-devices/emergency-situationsmedical-devices/eua-authorized-serology-test-performance. Accessed May 6, 2020.

- 2020c. LabCorp COVID-19 RT-PCR test EUA summary, undated. https://tinyurl.com/yd66fxea. Accessed May 6, 2020.

World Health Organization. 2020. "Immunity passports" in the context of COVID-19 scientific brief. https://www.who. int/publications-detail/immunity-passports-in-the-context-ofcovid-19. Accessed May 6, 2020.

Publisher's note Springer Nature remains neutral with regard to jurisdictional claims in published maps and institutional affiliations. 